\title{
NECİP CELÂL ANDEL VE TANGOLARI ÜZERİNE MÜZIKKSEL BİR İNCELEME
}

\section{Erdal KURTÇU $\mathbf{1}^{1}$}

Özet

Tango terimi, bir dansı ve aynı zamanda bir müzik türünü ifade eder. Dansla birlikte ortaya çıkan bu müzik türü, 1900'lü yılların başında tüm Dünya'yı etkilemiştir. Ülkemizde de o yıllardan günümüze, toplumun her katmanından geniş kitlelere hitap etmiş ve batı kökenli müzik türleri arasında en fazla benimsenen müzik türlerinden biri olmuştur. Ülkemizde ilk sözlü Türk tangosu Necip Celâl Andel tarafindan bestelenmiştir. Bestecinin eserleri, günümüzde dahi genç yaşlı birçok insanın zihnindeki yerini korumaktadır. Buna karşı, hem kendisi hem de eserleri ile ilgili az sayıda çalışma bulunmaktadır. Bu çalışmada, Türk tango müziğinin oluşumu ve gelişimi ele alınarak, Necip Celâl Andel'in Türk tango müziği içerisindeki yeri, önemi, ayrıca tangolarının teknik ve biçimsel özellikleri ile ilgili detaylı bilgilere ulaşılmıştır.

Anahtar Kelimeler: Tango, Türk tango müziği, Necip Celâl Andel.

\section{A MUSICAL EXAMINATION ON NECIP CELÂL ANDEL AND HIS TANGOES}

\begin{abstract}
The term tango refers to a kind of dance as well as a genre of music. Emerging together with dance, this music genre influenced the whole world in the early 1900s. In our country, since those years, it has appealed to a wide audience from all segments of the society, becoming one of the most appreciated music genres among western music genres. The first oral Turkish tango in our country was composed by Necip Celâl Andel. Even today, the composer's works preserve their place in the minds of many young and old people. On the other hand, there are few studies on both the composer himself and his works. In this study, by addressing the formation and development of Turkish tango music, detailed information about the place and importance of Necip Celâl Andel in Turkish tango music, as well as the technical and formal features of tango have been evaluated.
\end{abstract}

Keywords: Tango, Turkish tango music, Necip Celâl Andel.

\section{GİRIŞ}

Tango kelimesinin kökeni ile ilgili birçok farklı görüş ve etimolojik tanım bulunmaktadır. Bu konuda, Hess (2007)'in farklı kaynaklardan derlediği bilgilerden bazıları şu şekildedir; İspanyolca'da bu sözcük 1803 'ten beri mevcuttur ve âşık kemiği anlamında kullanılır. Enrique Corominas, sözcügün 1836 'da Arjantin dansı anlamında kullanıldığını söyler. Şunu belirtir, Öncelikle Amerika'nın dışında Kanarya Adaları'nın bir dansı olarak ortaya çıktı, daha sonra Amerika'da görüldü ve burada Siyahların davul eşliğinde dans ettiği toplantılara bu ad verildi. Jose Gobello, XIX. yüzyıl başında, Buenos Aires’te Siyahların şenlik düzenlediği evlere tango dendiğini hatırlatır. Horacio Salas Portekiz kökenli bir sözcük olduğunu ifade eder. Uruguaylı

\footnotetext{
${ }^{1}$ Arş. Gör. Dr., Sivas Cumhuriyet Üniversitesi, Eğitim Fakültesi Güzel Sanatlar Eğitimi, e-posta: erdal_kurtcu@ hotmail.com, ORCID: 0000-0002-7370-6210
} 
sosyolog Daniel Vildart ise, tango sözcüğünün Afrika dilindeki tambo (tambur, davul) ya da tangir veya tocar'dan (dokunmak, bir enstrüman çalmak) geldiğini ifade etmektedir.

Bir dans ve müzik türü olarak tango, "XIX. yüzyıl sonlarına doğru Arjantin'in Rio Del Plata bölgesinde ve Uruguay'da ortaya çıkmıştır. Dramatik (dans, müzik, şarkı sözleri ve gösteri) bir anlatımdır." (Savigliano, 2004, s. 37). Tangonun ortaya çıkışı incelendiğinde, 1800'lü yıllarda, İtalya, İspanya, Fransa, Portekiz ve Macaristan gibi ülkelerden gelen birçok göçmenin Güney Amerika'ya yerleşmesi ve bu toplulukların, burada kurdukları yaşamları içerisinde karşılaştıkları ekonomik ve sosyal sorunlar, bu türün ortaya çıkmasında etkili olmuştur. Günümüzde salon müziği olarak kabul edilen tangonun ortaya çıkışı, "belli kesimlerin tercihi ile ters düşecek şekilde sıradan, acılı, kötü hayat koşulları yaşayan insanlardan ve onların yaptıkları danslardan gelmektedir." (Yener, 2020, s. 366).

Tango, 1900'lü yılların başında, tüm Dünya'yı etkilemiştir. “Müzikteki farklılıklar da (şarkı sözleri başta olmak üzere melodik yapılar vb.) belirleyici olmakla birlikte dansta da görülen farkl11ıklar tango içerisinde farklı stilleri yaratmıştır." (Aydınoğlu, 2011, s. 2).

\section{Tango Türleri ve Yapısal Özellikleri}

Tango temelde üç türe ayrılmaktadır. Bunlar; tango milonga, tango romanza ve tango cancion'dur. Hess (2007)'e göre; Tango-milonga kesinlikle enstrümantaldir ve ritmik özelliği çok belirgindir. En klasik örneği Julio De Caro'nun Boedo tangosudur (1928). Tango-romanza ister enstrümantal olsun ister vokal, daha lirik ve melodiktir son derece romantik bir metne sahiptir. En bilineni Fransisco De Caro'nun Flores negras'1dır (1928). Tango-cancion adından da anlaşılacağı üzere her zaman vokaldir, enstrümantal eşlik vardır. Duygusal niteliği çok güçlüdür. Bu tür tango 1930'lu yıllardaki sosyolojik bir gelişmeye denk düşer: Tango artık kenar mahallelerdeki batakhanelerden çıkmış, büyük şehrin popüler bir tarzı olmuştur. Tango şarkılarının sözleri, yine de son derce karamsar ve kadercidir; genellikle de patolojik biçimde dramatik terimlerle yaşamı ifade ederler. Şarkılı tangonun en iyi örneklerinden bazıları, Samuel Catriosta'nın Mi noche trieste'si (1915), Julio Cesar Sanders'in Adios Muchachos'u (1928), Enrique Delfino'nun Milonguita's1 (1920), ve Anibal Troilo'nun Sur'udur (1948).

Günümüzde tango ile ilgili birçok farklı sınıflandırma ve dünyanın farklı bölgelerinde şekillenen birçok stil bulunmaktadır. Tango'nun belli başlı bazı stilleri; Arjantin Tango, Tango Oriental (Uruguayo), Tango Canyengue, Tango Liso, Tango Salon, Tango Orillero, Tango Milonguero (Tango Apilado), Tango Nuevo (New Tango), Show Tango (Fantasia), Ballroom Tango, Finnish Tango (Fin Tango) olarak sıralanabilir. Bunların dışında ülke isimleriyle (Türk tangosu, Rus tangosu vb.) siniflandirmalar da mevcuttur.

Yarkın (2017)'a göre, tango müziği Eski Dönem (1880-1910) ve Yeni Dönem (1910Günümüz) olarak iki döneme ayrılmaktadır. 1880-1910 yılları arasındaki ilk dönem, tango müziğinin ortaya çıktığı yıllardan yavaş yavaş kabul edildiği yıllara kadar uzanmaktadır. 1910 ile günümüzü kapsayan ikinci dönemde ise insanlar göçle birlikte mutluluğun gelmediğini anlamıştır. Vatan hasreti ve eskiye duyulan özlem insanlarda hüzne sebep olmuş; parçalar melankolikleşmeye başlamıştır. 
Tango 1915 yılına dek iki zamanlı (2/4) ölçüsünü korumaktadır. Daha sonra, 4/4 ve 4/8'e daha sık rastlanır. 1955'ten sonra ise yeni ritmik karmalar gelişmiştir. Yapısal açıdan ilk tangolar üç kısımdan oluşur ama 1915'ten sonra iki kısımlı tango öne çıkmaktadır. Tangonun standart biçimini ilk oluşturan bestecinin Delfino olduğu kabul edilir: 14 ölçüden 20 ölçüye dek giden iki eşit bölüm ve ikinci bölümde ana tonalitenin -baskın ya da nispi- minörü şeklinde yapılandırılır (Hess, 2007, s. 66).

Başlangıçta, ağır tempoda, senkoplara yer verilen 2/4 lük ölçüdeki Arjantin Tango, Küba'nın tipik bir Latin halk dansı özelliğindeki Habanera'sından esinlenmiştir. Ancak tangonun etkileyici yönleriyle öne çıkması, Arjantin'in geleneksel şarkıları olan Milonga'dan yararlanarak Tango milonga adı altında 4/8 lik ya da 4/4 lük ölçüde hızlı tempolu bir dans olarak gerçekleşmiştir. 1930'lu yıllardan başlayarak Astor Piazzola'nın ortaya çıkardığı Tango nuevo ise çağdaş müzik anlayışıyla caz öğelerinden yararlanan modern özellikler taşımıştır (Say, 2005, s. 438).

\section{Türkiye'de Tango}

Osmanlı'nın son dönemlerinde, birçok alanda olduğu gibi müzik alanında da bir modernleşme süreci başlamış ve bu süreç Cumhuriyet dönemi ile devam etmiştir. $\mathrm{Bu}$ süreçte ülkemizde dünya müzikleri ile ilgili de çalışmalar yapılmıştır. "Türk müziğinin Avrupa müziği besteleme teknikleriyle işlenmesi fikri, batılılaşma ve modernizm algısının bir ürünüdür. Piyanonun Türk müziğinin icrasında yer almasıyla makam kullanımından uzaklaşılmış, eserler polifonik yapıda oluşturulmuştur.” (Demirbaş, 2017, s. 170).

"Türk tangolarının da müzik bakımından bu özellikleri taşıdığı tespit edilir. Türk tango müziği, güfteleriyle benzerlik gösteren aşk, tutku, özlem, ayrılık temalı sözler ve makamın dokusunu barındıran, Batı müziği tarzında bestelenmiş ezgilerin birleşimiyle, Türk müziğinin modernleşmesinin en belirgin örneklerinden birini oluşturur.” (Demirbaş, 2017, s. 170).

Atamert'e göre, Türk tangosu “Türkiye Cumhuriyeti'nin yeni görüntüsünü temsil etmek için, özellikle cumhuriyetin kuruluş yıldönümü gibi zamanlarda devletin üst düzey kutlamalarında bulunan yabancı konuklara, Türkiye'nin modernleşme sürecinin başarısını kanıtlamak çabasıyla 'resmi' müzik haline getirilmiştir. Çağdaşlaşma sürecinde olan yeni Türkiye Cumhuriyeti devletinin inşasında, küresel bir malzeme olan (ve o dönemde tüm dünyada moda olmaya başlayan) tango, yerelleştirilerek kullanılmıştır.” (Aydınoğlu, 2011, s. 11).

Türkiye'de tango, dans müziği olmanın ötesinde öncelikle bir şarkı olarak kabul edilmiştir (Sarıboğa, 2019, s. 269). Ülkemizde tango dansının versiyonları daha az vücut teması esasına dayalı (Ballroom Tango) ama bununla beraber başlarda pek çokları için yine de şok edici olmuştur (Yener, 2020, s. 369). Buna karşı, tangonun ülkemizde Arjantin tangosunun aksine ahlaki değerlerimize uygun bir biçim ile şekillendiğini söylemek mümkündür.

Tango, Türkiye'de 1930'lu yıllarda yükselmeye başlamıştır. 50'li yıllara kadar altın çağını yaşamış lakin ilgi 60'lı yıllarda Batı müziğinin tüm türlerinde ürünler verilmeye başlanınca azalmıştır. Nedim Erağan, "Tramvaylı Günler ve Eski Tangolar" adlı kitabında, 1937-38 yıllarında Şirket-i Hayriye vapurlarında tango plaklarının çaldığını söylemektedir. Bu, tangonun 
o yıllardaki saltanatını gösteren güzel bir örnektir. Ancak 70'li yıllardan sonra eski popülaritesini kaybederek unutulmaya yüz tutmuştur (Meriç, 2017).

Ülkemizde tango müziği, Türkçe sözlü tangolar ve Arjantin tangolar olmak üzere iki ayrı şekilde kendini göstermiştir. Bu süreçte tango orkestraları kurulmuş, konserler, festivaller, radyo programları hazırlanmış, plak, kaset ve cd kayıtları yapılmış, içinde bulunduğumuz yüzyılda ise yeni gruplar kurularak tangonun yaşatılması için çalışmalar yapılmaktadır (Sarıboğa, 2019, s. 272).

İlk Türk tangosu, Muhlis Sebahattin Bey'in bestelediği “Tango Türk” isimli enstrümantal eser olarak kabul edilmektedir. "İlk sözlü Türk tangosu ise, 1928 y1lında Necip Celâl Andel'in bestelediği "Mâzi" isimli eseridir (Ünlü, 2004, s. 8). Ülkemizde tango müziğinin bazı önemli bestecileri, başta Necip Celâl Andel, Fehmi Ege ve Necdet Koyutürk olmak üzere, Kadri Cerrahoğlu, Ziyaettin Sarıkartal, Halit Bedii Akçay, Nusret Rıfkı ve Mustafa Şükrü'dür. Ülkemizin en önemli tango yorumcularından bazıları ise, Seyyan Oskay, İbrahim Özgür, Selçuk Kaskan, Secaettin Tanyerli ve Celal İnce olarak siralanabilir.

\section{Necip Celâl Andel}

1908 yılında İstanbul'da doğmuştur. Babası Mehmet Celâlettin Bey, annesi ise Emine Hanım'dır. Mehmet Celalettin Bey hukuk eğitimi almış, adliye nazırlığı ve hukuk müderrisliği görevlerinde bulunmuştur. Kanun çalmaktadır. Necip Celâl Andel, babasının kanun çalmasından etkilenerek, 5 - 6 yaşlarında iken kanun ile müziğe başlamıştır.

Andel, yüksek maddi olanaklara sahip bir ailenin üyesidir. Ağabeyi Sadri Celâl Avrupa'da eğitim görmekte ve o da piyano çalmaktadır. "Bir hastalık sonucunda genç yaşta gözleri ileri derecede bozulan Andel, 1924 yılında ağabeyinin eğitim gördüğü Almanya'ya gitmiştir. Müziğe olan ilgisi burada daha da artmıştır." (Kandemir, 1935).

Kemana ve klasik müziğe olan ilgisi küçük yaşlarda başladıysa da bu alanda gelişmesi Almanya'ya gittikten sonra olmuştur. Almanya'da ne süre kaldığg tam olarak bilinmediği gibi oraya gidiş nedeni de tam belli değildir. Bazı kaynaklarda gözlerini tedavi ettirmek için gittiği söylenmektedir. 1924 sonbaharında kaldığ 1 Almanya'da keman öğrencisi olduğu Ernst Schnabel, Andel'in kabiliyetine hayran olmuş ve bu hayranlığını (o zaman da görme bozukluklarından muzdarip bu talebesi için) "Eğer tıbben mümkün olsa gözlerimden birini Necip'e verirdim" diyerek belirtmiştir (Sevsay, 2019, s. 65).

Türkiye’ye döndüğünde eğitimine Almanya eğitimli Tahir Sevenay ile devam etmiştir. İyi derecede keman çalmasının yanında, ud, mandolin ve piyano gibi çalgıları da çalabilmektedir. "Andel ona müziği sevdiren kişinin 4 y1l boyunca ders aldığı Tahir Sevenay olduğunu belirtmiştir." (Kandemir, 1935). Bu dönemde dans müziğine ilgi duyan besteci, dinlediği eserlerde ezgisel yapının basit olduğunu ve bu müzikleri, hatta biraz daha iyilerini, kendisinin de besteleyebileceğini düşünerek besteciliğe ilk adımını atmış ve ilk eserleri olan Sarı Yapıncak ve Daktilo isimli eserlerini besteleyerek başarılı olmuştur.

Sevsay (2019)'a göre, Andel'in eserlerindeki üstün kalitenin en önemli nedenlerinden biri, klasik müzik alanındaki tecrübeleridir. Besteci elde ettiği klasik müzik notalarını gözlerinin müsaade ettiği oranda incelediği, bilgisini artırdığg ve tecrübesini geliştirdiği bilinmektedir. 
Müziğin her türlüsüne gösterdiği ilgiyi klasik müziğe de göstermiş, hatta ömrünün son yıllarında bu konuya daha da eğilmiştir. Ancak besteci, Türk müziği ve Batı müziği ayrımına karşı çıkmıştır. Orkestrasyon konusuna çok ilgi duyduğu için senfonik eserler besteleme düşüncesindeymiş. Özellikle Türk motifleri kullanılan senfonik besteler yapmaya hazırlanıyormuş. Arşivinden çıkan ve kimin yazdığ imzasından okunamayan belgelerde orkestrasyon konusunda tavsiyeler aldığ görülmektedir. Son eseri olarak yazmaya başladığı ve ölümünden yaklaşık 60 yıl sonra evindeki bir sandıktan gün 1şı̆̆ına çıkan obua konçertosuna, Haseki Hastanesi’ndeki son günlerini geçirdiği odasında bile devam etmiş, ancak ömrü yetmediği için bu çalışmasını tamamlayamamıştır (Sevsay, 2019, s. 66).

Besteci orkestrasyon konusuna duyduğu ilgiyi, bir röportajında şu sözlerle ifade etmiştir:

-İnşallah gözlerim açılsın, çok çalışacağım... Her şeyden evvel iyi bir kompozitör olmak isterim ve ilk işim bir operet yapmak olacaktır. Şimdi en büyük zevkim, kendi kendime orkestrasyon yapmak. Dünyada bundan güzel bir şey yok. Bu, daha olmamış, tamamlanmamış, pişmemiş müziği kafamın içinde kendi kendime dinlerken duyduğum zevk sonsuz (Kandemir, 1935).

1928 yılında, sözleri Necdet Rüştü Efe'nin yazdığ 1 Mâzi isimli ilk tango eserini bestelemiştir. Bu eser ülkemizde bestelenen ilk sözlü Türk tangosu olarak kabul edilmektedir. İlk kez Seyyan Hanım (Oskay) tarafından seslendirilerek plak kaydı alınmıştır. Eser bu dönemde büyük beğeni alarak, radyonun da etkisiyle hem Necip Celâl Andel'in, hem de Seyyan Oskay'ın ün kazanmasını sağlamıştır.

Bu eseri, Alman sinema yıldızı ve şarkıcı Evelyn Hold, Berlin radyosunda Türkçe olarak y1llarca seslendirmiş̧tir (Toros, 1987, s. 20). 1933 y1lında İstanbul'a gelen ve Hale Sineması'nda bir konser veren sanatçı, Andel'in kendisini araması sonucu büyük bir sevinçle onu konsere davet etmiştir. Burada Andel ile tanışmışlar ve ertesi gün bir araya gelmek üzere vedalaşmışlardır. Bu son buluşmanın ardından besteci, o gecenin anısına Özleyiş adlı eserini besteleyerek Evelyn Hold'a ithaf etmiştir. Bu buluşmaya dair tüm bilgiler, Andel'in günlüğüne yazdığı notlardan Deniz (2020) tarafından şöyle aktarılmıştır:

"Suadiye plajı bana bu aksam her zamankinden daha güzel geliyor. Mehtap denizin üzerine vurmuş, etraf sessiz, konuşmadan geceyi dinliyoruz. Oldukça kalabalığız, kıymetli artistimiz Feriha Tevfik, ağabeyim, Yusuf Kenan, Hollywood muhabiri Turan Aziz ve daha birçok sevdiğim arkadaşlarım... Simdi ellerimde akordeon, parmaklarım tuşların üzerinde, içimden kopup gelen bütün duygularımı söylüyor. Kendimden geçmiş bir halde mütemadiyen çalıyorum. O da etrafin isteği üzerine Mâzi’ yi söyledi. Bu kadar duyarak çaldığımı hatırlamıyorum. Benden bizzat keman çalmamı istedi. Schuman'ın Aksam şarkısı, Fibich Poem ve onun çok sevdiği Toselli serenad... Kemandan yükselen sesler yavaş yavaş sönerken, mehtap da artık kayboluyordu. Gazino tamamıyla bizim için kapatılmıştı. Onunla tadına doyulmaz, rüya gibi bir dans ettik, eğlendik. Dans ederken bana: 'Mâzi'yi hiç unutmayacağım, dudaklarımdan hiç eksik etmeyeceğim' dedi. Vakit gece yarısını çoktan geçmişti. İçimden coşup gelen bir takım sesler var. Kafamın içinde mütemadiyen dolaşıyor, fakat bir türlü toparlayamıyorum. İsteği üzerine akordeonu elime alarak, 'Ayrılık'ı çaldım. Yanıma yaklaştı, dans eder gibiydik yine ama ele ele tutuşmuyorduk. İşte o anda bana, üzerine çok samimi sözler yazılmış bir fotoğrafını verdi ve sonra tekrar dans etmeye 
başladık. Ona bir cesaret: 'Ne olur bu gece hiç bitmese' dedim. Ben bu sözleri söylerken, plajın saati 3'ü çalıyordu. Sabah gidecekti. 'Beni unutma' dedim. 'Sen de' dedi. O aksam ağabeyimin Erenköy'ündeki köşkünde kalacaktım. Yayan yürümeyi tercih ederek sessizce eve geldim. Zihnim hep onunla meşgul. O melodiyle meşgul. Öylece pencerenin kenarına oturdum. Dışarıda yaz böcekleri, kurbağalar ve sık çalılar arasında duyulan bir tek bülbül sesi... Ortalık hafifçe aydınlanır gibi oldu. Gayri iradi piyanoya doğru yürüdüm. Başımda inanılmaz bir ağrı. Hemen oturup en sessiz pedala basarak içimden gelen sesleri yavaş yavaş çalmaya başladım. Çünkü başka türlü olmayacaktı. Mümkünü yoktu. O gece yazdı̆̆ım beste ise şöyleydi...

Sevdim bir genç kadını,

Ansam onun adını,

Her şey beni ona bağlar,

Kalbim durmadan ağlar,

Kemanımla ona bir ses verebilseydim eğer,

$\mathrm{Bu}$ sesimle ona ersem bana dünyaya değer,

Ne yazık ki deniz engin su ufuklar ölgün,

Bin elemle doluyor her yeni gün..." (Deniz, 2020).

Besteleniş hikâyesi ve sözleri yukarıda sunulan ve halk arasında Sevdim Bir Genç Kadını adıyla tanınan Özleyiş isimli eseri de, Mâzi kadar ün kazanmış ve birçok filmde de kullanılmış önemli eserlerinden biridir. Ayrıca bu eser yurt dışında da büyük bir ilgi görmüştür.

"Özleyiş, Türkçe dışında dört dile çevrilmiştir. Almanca (Fritz Schwanberg'in sözleriyle "Sehnsucht"), Fransızca (Fazıl Senâi Sarper'in sözleriyle "Amertume") ve İspanyolca (J.G. Blanca Villata'nın sözleriyle "Te Esperaba") seslendirilen bu tangoyu, Ayten Alpman, "Tango Tomorrow" adıyla ve İngilizce sözlerle seslendirmiştir.” (Meriç, 2017).

Andel'in günümüzde bilinen eserleri; 11 tango, keman konçertosu, keman sonatı, keman etütleri, obua konçertosu (tamamlanmamış), viyolonsel konçertosu ve çeşitli liedler olarak sıralanabilir. Ayrıca besteci, 1948 yılında Fenerbahçe Marşı'nı yazmıştır.

Hosan (1953)'ın Andel ile gerçekleştirdiği röportajında, eserlerinin sayısına dair sorduğu bir soruya besteci şu cevabı vermiş̧ir;

-Pek çok... Fakat basılmış olan 18 tane. Bunlar hafif müzik eserleri. Yakında, iki ciddi eserimi de dinleyeceksiniz. Birincii halkımızın çok sevdiği çellist Gaspar Cassado'nun arzusuyla ve tamamen Türk musikisi makamlarıyla bestelenmiş tam formunda üç kısımlık bir viyolonsel konçertosu. Orkestrasyonu çok büyük. Cassado son gelişinde kendisiyle müteaddit çalışmalarım oldu. Eser tamam ve yakında kendisine göndereceğim. İkinci eser halen türk uyruğunda olan büyük keman üstadı Vasa Prihoda'ya ithaf ettiğim keman ve piyano için Rüzgar Sanatı. Bu da üç kısım: 1) Rüzgar, 2)Akşam, 3)Fırtına... Çalınması güç olan bu sonatın ana motifleri yine bizim musikimizn renklerinden. Her iki eserin uzunluğu 35 dk (Hosan, 1953). 
Besteci aynı röportajda en çok sevdiği bestecinin kim olduğunun sorulması üzerine, pek çok eser ve besteciyi sevmesine rağmen en çok sevdiği bestecinin J. S. Bach olduğunu belirtmiştir. Müziğimizde Münir Nurettin, Necmi Rıza, Safiye Ayla, Müzeyyen Senar, Haluk Recai, Ercüment Batanay, İzzettin Ökte ve Şükrü Tunar'ın ruhuna hitab eden ve beğendiği sanatkârlar olduğunu söylemiştir (Hosan, 1953).

Necip Celâl Andel, hayatının son zamanlarını gözlerindeki rahatsızlığın ilerlemesi sonucu karanlıkta geçirmiş ve kanser hastalığı sebebiyle 29 Kasım 1957'de hayatını kaybetmiştir.

\section{YÖNTEM}

$\mathrm{Bu}$ araştırmada betimsel analiz yöntemi kullanılmıştır. Tanrı̈ğen (2012)'in Erkuş (2005)'tan aktardığı bilgiye göre, betimsel araştırmalar olayı olduğu gibi araştırmaya ve var olan durumu belirlemeye çalışan araştırmalardır. Bu tür araştırmalarda, ele alınan olaylar ve durumlar ayrıntılı bir şekilde araştırılmakta, daha önceki olaylar ve durumlarla ilişkisi incelenerek, "ne" olduklarını betimlenmeye çalışılmaktadır.

Araştırmada genel tarama modeli kullanılmıştır. "Genel tarama modelleri, çok sayıda elemandan oluşan bir evrende, evren hakkında genel bir yargıya varmak amacı ile evrenin tümü ya da ondan alınacak bir grup, örnek ya da örneklem üzerinde yapılan tarama düzenlemeleridir" (Karasar 2018, s.111). "Sosyal bilimlerde sıkça tarama araştırmaları yapılır. Bu araştırmalarda araştırmacı farklı ve çok sayıda kaynaktan çeşitli yöntemlerle nicel verilere ulaşmayı, nicel verilerden oluşturulmuş istatistiklerle genel tabloyu görmeyi amaçlar. Belirlenen yöntemle kesitsel, boylamsal ve geçmişe dönük tarama araştırmaları yapılır" (Karahasanoğlu ve Yavuz, 2018: 10).

Araştırmada, öncelikle konunun tarihsel ve bilimsel gelişimi ele alınarak tango müziğinin ortaya çıkışı, dünyada ve ülkemizde ki gelişim süreci ve Necip Celâl Andel ile ilgili detaylı bilgilere ulaşılmıştır. Ardından Andel'in tango eserlerinin tonal, ritimsel, makamsal, biçimsel ve sözel özellikleri tespit edilmiştir. Araştırma sonucunda, elde edilen verilerin ulaşılan tarihsel bilgilerle birlikte yorumlanmasıyla sonuçlara ulaşılması hedeflenmiştir. Araştırmanın evreni tango müziği, örneklemi ise Necip Celâl Andel'in tüm tangolarını oluşturan 11 adet eseri ile oluşturulmuştur.

\section{BULGULAR}

Bu bölümde Necip Celâl Andel'in, araştırmanın örneklemini oluşturan eserlerinin analizine ilişkin bulgulara yer verilmiştir. Eserler bestelenme sırasına göre listelenerek, müziksel özellikleri ile ilgili elde edilen bulgular tablolar halinde sunulmuştur. Orijinal kaynak bilgileri Sevsay (2019)'ın çalışmasından elde edilmiştir. Bestecinin "Damla Damla" isimli son eseri yayımlanmadığı için söz analizi haricinde inceleme dışında bırakılmıştır. 
Tablo 1. Necip Celâl Andel Tangolarının Tonal ve Ritimsel Özellikleri

\begin{tabular}{llll}
\hline Eser & Opus Numarası & Orijinal Ton & Ritim Kalıbı \\
\hline Mâzi & Op.2 & La Minör & $4 / 8$ \\
Ayrılık & Op.3 & Re Minör & $2 / 4$ \\
Suna & Op.6 & Re Minör & $4 / 8$ \\
Özleyiş & Op.7 & Mi Minör & $4 / 8$ \\
Kimse Sevgimi Bilmez & Op.9 & Fa Diyez Minör & $4 / 8$ \\
Yıllar & Op.10 & Do Minör & $4 / 8$ \\
Günler & Op.11 & Do Minör & $4 / 8$ \\
Bir An için & Op.12 & Re Minör & $4 / 8$ \\
Benim Şarkım & Op.14 & Mi minör & $4 / 8$ \\
Geçmiş Zaman Olur Ki & Op.15 & Do majör & $4 / 8$ \\
\hline
\end{tabular}

Necip Celâl Andel'in tangolarının tonal ve ritimsel özellikleri tabloda görülmektedir. Bestecinin 3 eseri re minör, 2 eseri do minör, 2 eseri mi minör, 1 eseri la minör 1 eseri fa diyez minör ve 1 eseri do majördür. Eserler dört ve iki zamanlı ölçüde yapılandırılmıştır. Bestecinin 9 eseri minör ve yalnızca 1 eseri majör tondadır. Benzer şekilde 9 eseri dört zamanlı ve 1 eseri iki zamanlı olarak yapılandırılmıştır. Bu bilgilerle, Necip Celâl Andel'in tangolarında en fazla dört zamanlı ölçü ve minör tonu tercih ettiğini söylemek mümkündür.

Eserlerin orijinal ton ve ritimleri tabloda belirtildiği gibi olmakla birlikte günümüzde farklı ses grupları ve çalgılar için birçok tona uyarlanmış notasyonları mevcuttur.

Tablo 2. Necip Celâl Andel Tangolarının Makam Etkileri Analizi

\begin{tabular}{ll}
\hline Eser & Makam Etkileri \\
\hline Mâzi & Nihavent, Buselik \\
Ayrılık & Nihavent, Buselik \\
Suna & Nihavent, Buselik \\
Özleyiş & Nihavent, Buselik \\
Kimse Sevgimi Bilmez & Nihavent, Buselik \\
Yıllar & Nihavent, Buselik \\
Günler & Nihavent, Buselik \\
Bir An için & Nihavent, Buselik \\
Benim Şarkım & Nihavent, Buselik \\
Geçmiş Zaman Olur Ki & Rast, Mahur, Çargâh \\
\hline
\end{tabular}


Eserler tonal yapıda bestelenmiş olmakla birlikte makamsal etkiler barındırmaktadır. Tabloda görüldüğü gibi, incelenen eserlerin makamsal etki analizi sonucunda elde edilen bulgulara göre, Nihavent, Buselik, Rast, Mahur, Çargâh makamlarının etkilerine rastlanmıştır. Örneklemi oluşturan eserlerin 9 tanesinde Nihavent - Buselik ve 1 tanesinde Rast - Mahur Çargâh etkileri saptanmıştır. Bu sonuca göre bestecinin, eserlerinde en fazla Nihavent - Buselik makamlarının dokusunu kullandığını söylemek mümkündür.

Tablo 3. Necip Celâl Andel Tangolarının Form Analizi

\begin{tabular}{llllc}
\hline Eser Adı & Giriş & I. Bölüm & II. Bölüm & III. Bölüm \\
\hline Mâzi & 8 ölçü & 16 ölçü & 16 ölçü & - \\
Ayrılık & 8 ölçü & 16 ölçü & 16 ölçü & - \\
Suna & 4 ölçü & 16 ölçü & 16 ölçü & - \\
Özleyiş & 4 ölçü & 16 ölçü & 16 ölçü & - \\
Kimse Sevgimi Bilmez & 4 ölçü & 16 ölçü & 16 ölçü & 16 ölçü \\
Yıllar & 4 ölçü & 16 ölçü & 16 ölçü & 16 ölçü \\
Günler & 16 ölçü & 16 ölçü & - & - \\
Bir An İçin & 12 ölçü & 16 ölçü & 16 ölçü & - \\
Benim Şarkım & 5 ölçü & 16 ölçü & 16 ölçü & - \\
Geçmiş Zaman Olur Ki & 4 ölçü & 16 ölçü & 16 ölçü & -
\end{tabular}

Tabloda görüldüğü gibi, Necip Celâl Andel'in "Mazi, Ayrılık, Suna, Özleyiş, Bir An İçin, Benim Şarkım ve Geçmiş Zaman Olur Ki” isimli eserleri iki bölümlü, "Kimse Sevgimi Bilmez ve Yıllar" isimli eserleri üç bölümlü, Günler isimli eseri ise tek bölümlü biçimde yapılandırılmıştır. Sayısal açıdan değerlendirildiğinde, 7 eseri iki bölümlü, 2 eseri üç bölümlü ve 1 eseri tek bölümlüdür. Buna göre bestecinin eserlerinde klasik tango formuna uygun biçimde en fazla iki bölümlü formu kullandığı görülmüştür.

Tablo 4. Necip Celâl Andel Tangolarının Konu Analizi

\begin{tabular}{ll}
\hline Eser & Konu \\
\hline Mâzi & Geçmişte yaşanmış hüzünlü bir aşk hikâyesi. \\
Ayrılık & Giden sevgiliye duyulan özlem. \\
Suna & Suna'ya duyulan aşka dair duygular. \\
Özleyiş & Uzaklardaki sevgiliye duyulan özlem. \\
Kimse Sevgimi Bilmez & Gizli bir aşk hikâyesi. \\
Yıllar & Yıllar önce yaşanmış bir aşkın hatıraları ve ona duyulan özlem. \\
Günler & Bestecinin karamsarlıkları ve gelecek için umutları.
\end{tabular}


Bir An İçin

Benim Şarkım

Geçmiş Zaman Olur Ki

Damla Damla
Sevgiliye hissedilen güzel duygular.

Eski sevgiliden hatıra kalan ve sahilde söylenen şarkı.

Geçmişte yaşanan aşkların mutlu hatıraları.

Semâvi duygular.

Tabloda görüldüğü gibi, Necip Celâl Andel'in eserlerinin 9 tanesinde aşk, özlem ve ayrılık temalarını kullandığı görülmüştür. Buna karşı, 1 eserinde hayata dair karamsarlıklar ve 1 eserinde semavî duygular ele alınmıştır. Bu sonuçlara göre bestecinin tangolarında sıklıkla aşk, özlem ve ayrılık temalarını kullandığı görülmektedir. Bu bilgilere ek olarak, bestecinin birçok eserinde yer verdiği karanlık, 1şıksız, gece ve renksiz ifadeleri dikkat çekmektedir.

Tablo 5. Necip Celâl Andel Tangolarının "Söz Yazarı ve İthaf” Dağılımı

\begin{tabular}{llll}
\hline Eser & Söz Yazarı & Fransızc Söz & İthaf \\
\hline Mâzi & Necdet Rüştü Efe & Fazıl Senâ̂ Sarper & $\begin{array}{l}\text { Charlie } \\
\text { Guadriot }\end{array}$ \\
Ayrılık & Necip Celâl Andel & - & - \\
Suna & Bülent Nuri Esen & Fazıl Senâ̂ Sarper & $\begin{array}{l}\text { Münir Nureddin } \\
\text { Selçuk }\end{array}$ \\
Özleyiş & Bedri Noyan - Necip & Fazıl Senaî Sarper & Evelyn Holt \\
& $\begin{array}{l}\text { Celâl Andel(Almanca- } \\
\text { İspanyolca-İngilizce) }\end{array}$ & & \\
Kimse Sevgimi Bilmez & Bedri Noyan & - & Barnabas \\
& & & Goczy \\
Yıllar & Bedri Noyan & Fazıl Senaî Sarper & - \\
Günler & Bedri Noyan & - & Xavier Cugat \\
Bir An İçin & Bedri Noyan & - & - \\
Benim Şarkım & Necip Celâl Andel & - & - \\
Geçmiş Zaman Olur Ki & Necip Celâl Andel & - & - \\
Damla Damla & Necip Celâl Andel & - & - \\
\hline
\end{tabular}

Bestecinin eserlerinde kendisi dışındaki söz yazarları Bedri Noyan, Necdet Rüştü Efe ve Bülent Nuri Esen'dir. Eserlerin Fransızca uyarlamaları ise Fazıl Senaî Sarper tarafından yapılmıştır. Bestecinin Özleyiş isimli eserinin Fransızca dışında, Almanca, İspanyolca ve İngilizce uyarlamaları da bulunmaktadır.

\section{SONUÇ}

19. yüzyılda Arjantin'de ortaya çıkan tango, 1900'lü yılların başında dünyanın birçok ülkesinde popüler hale gelmiştir. Tango müziği de dansla birlikte gelişmiş ve her toplumda farklı kültürel etkilerle şekillenerek (Arjantin Tangosu, Fransız Tangosu, Türk Tangosu gibi) çeşitli 
türler ortaya çıkmıştır. Ülkemizde tango, Arjantin tangosu ve Türkçe sözlerle bestelenen Türk tangosu olarak iki farklı şekilde gelişim göstermiştir. Cumhuriyet sonrası dönemde yeni Türkiye'nin modern yüzünü göstermek amacıyla devletin üst düzey toplantılarında da sergilenen bir müzik türü olan tango, bu yönüyle, modernleşme süreci etkilerinin müzik alanındaki belirgin örneklerinden birini oluşturmaktadır.

Türk tango müziği, ülkemizde batı kökenli müzik türleri arasında halk tarafından en fazla benimsenen müzik türlerinden biridir. Bu duruma, Necip Celâl Andel'in Türk müziğinin dokusunu kullandığı ve Türkçe sözlerle bestelediği eserlerinin katkısı oldukça fazladır. Osmanlı'nın son dönemlerinde tango üzerine bazı enstrümantal çalışmalar yapılmış olsa da yeterince benimsenmemiştir. Bu sebeple Türk tango tarihinin Necip Celâl Andel ile başladığını söylemek mümkündür. İlk Türk tangosu, Muhlis Sebahattin Bey'in bestelediği "Tango Türk" isimli enstrümantal eser, ilk sözlü Türk tangosu ise, Necip Celâl Andel'in bestelediği Mazi isimli eserdir.

Necip Celâl Andel Türk - Batı Müziği ayrımına karşı bir duruş sergileyerek eserlerinde Türk müziğinin motifleri ile batı müziği formlarını birlikte kullanmayı tercih etmiştir. Son yıllarında Türk müziği motifleri ile senfonik eserler besteleme düşüncesinde olsa da ne yazık ki ömrü yetmemiştir. Necip Celâl Andel'in tangolarında Nihavent - Buselik, Rast - Mahur - Çargâh makamlarının etkileri görülmektedir. Bestecinin eserleri tonal açıdan değerlendirildiğinde çoğunlukla minör tonları, makamsal açıdan değerlendirildiğinde ise çoğunlukla Nihavend Buselik makamlarının dokusunu kullandığı görülmektedir.

Tango formu, temelde 2/4, 4/4 ve 4/8 zamanl1, iki - üç bölümlü ve bölümler 14-20 ölçü olacak şekilde yapılandırılmaktadır. Necip Celâl Andel'in eserleri biçimsel açıdan değerlendirildiğinde, eserlerinin çoğunlukla 4 zamanlı, 2 bölümlü ve 16 ölçüden oluşan bölümlemelerle oluşturulduğu görülmüştür. Buna göre Andel'in, eserlerinde genellikle klasik tango formuna bağlı kaldığını söylemek mümkündür.

Necip Celâl Andel'in eserlerinin sözleri incelendiğinde bestecinin, eserlerinin büyük bir kısmında, "aşk, özlem ve ayrılık" temalarını kullandığı görülmüştür. Buna karşı "Günler" isimli eserinde bestecinin o güne dair karamsarlıkları konu edilmiş ve son tangosu olan "Damla Damla" isimli eserinde ise, içerisinde semavî düşünceler barındıran bir tema kullanılmıştır. İncelenen eserlerin birçoğunda, "karanlık, gece, 1şıksız ve renksiz" ifadelerinin kullanıldığ görülmüştür. Bu durum, bestecinin ilerleyen görme bozukluğu ile ilgili rahatsızlığ zorlukların eserlerine yansıması olarak düşünülebilir.

Besteci, son dönem eserlerini kendi yazdığı sözler üzerine bestelemiş, Mâzi, Suna, Özleyiş ve Yı1lar isimli eserlerine ayrıca Fransızca sözler de yazılmıştır. Özleyiş isimli eserinin, Fransızca dışında Almanca, İspanyolca ve İngilizce sözlerle de yayımlanmış olması, eserin yurt dışında da sergilendiği konusunda bizlere fikir verebilir. Bestecinin bazı eserleri dönemin önemli filmlerinde film müziği olarak da kullanılmıştır.

Necip Celâl Andel, eserleri günümüzde dahi genç yaşlı birçok insanın zihnindeki yerini koruyan, ülkemizin değerli bestecilerindendir. Bu çalışma ile bestecinin hayatı, eserleri, müzik yaşamı ve ayrıca araştırmaya konu olan eserlerinin müziksel özellikleri ile ilgili bilgiler elde 
edilmeye çalışılmıştır. Benzer çalışmaların diğer tango bestecilerimiz üzerinde yapılması ile birlikte Türk tango müziğinin gelişimi ile ilgili daha detaylı bilgilere ulaşılması mümkün olacaktır.

\section{KAYNAKÇA}

Atamert, E. (2001). Tango and The Invention of Modern Turkey. [Yüksek Lisans Tezi, İstanbul Teknik Üniversitesi]. İstanbul.

Aydınoğlu, O. (2011). Toplumsal Cinsiyet Rolleri Açısından Tango'nun Diyalektiği. Porte Müzik ve Dans Araştırmaları Dergisi, 2(3), 1-12. .

Demirbaş, Tül, A. (2017). Milonganın Eşik Bekçileri: Tango DJ'leri, Sosyoloji Dergisi, 163-178. https://doi.org/10.26650/SJ.38.1.0001

Deniz, T. (2020). Necip Celâl Andel ve Kemancının Sandığı. Erişim Tarihi: 10.02.2021. https://www.fotokart.shop/blog/necip-celal-andel-ve-kemancinin-sandigi/

Erağan, N. (1994). Tramvaylı Günler ve Eski Tangolar. Altın Kitaplar.

Erkuş, A. (2005). Bilimsel Araştırma Sarmalı. Seçkin Yayıncılık.

Hess, R. (2007). Tango. Dost Kitabevi Yayınları.

Hosan, B. (1953, 13 Ağustos). Müzik Söyleşileri: Necip Celâl Andel. Radyo Alemi. Arşiv Çalışması: Zeynep Erdoğan, Dizgi, redaksiyon: Serhan Yedig. https://muziksoylesileri.net/arsivlerden/necip-celal-andel-cello-koncertomu-gasparcassado-keman-piyano-sonatimi-vasa-prihoda-icin-yazdim/

Kandemir. (1935). İnşallah Gözlerim Açılacak / Operet Besteleyeceğim. Arşiv Çalışması, Redaksiyon: Serhan Yedig. https://muziksoylesileri.net/arsivlerden/necip-celal-andelinsallah-gozlerim-acilacak-operet-besteleyecegim/

Karahasanoğlu, S. ve Yavuz, E. D. (2018). Müzikte Araştırma Yöntemleri. İstanbul: Berceste Yayınevi.

Karasar, N. (2018). Bilimsel Araştırma Yöntemi: Kavramlar İlkeler Teknikler. Ankara: Nobel Akademik Yayıncılık

Meriç, M. (2017, 5 Şubat). Mazi dediğin: Plağa Alınan İlk Türkçe Tango ve Hatırlattıkları. Gazete Duvar. https://www.gazeteduvar.com.tr/yazarlar/2017/02/05/mazi-dedigin-plaga-alinanilk-turkce-tango-ve-hatirlattiklari

Sarıboğa, B. (2019). Tango Müziğinin Tarihsel Süreci ve Türkiye'de Tango Müziğine Genel Bir Bakış. Ordu Üniversitesi Sosyal Bilimler Araştırmaları Dergisi, 9(2), 263-273.

Savigliano, M. E. (2004). Tango Tutku'nun Ekonomi Politiği. Ayrıntı Yayınları.

Say, A. (2005). Müzik Ansiklopedisi. Müzik Ansiklopedisi Yayınları. Ankara.

Sevsay, E. (2019). Türk Tangosunun Kurucusu Necip Celâl Andel. Oğlak Yayıncılık.

Tanrıöğen, A. (2012). Bilimsel Araştırma Yöntemleri. Ankara: Anı Yayıncıllk. 
Toros, T. (1987, 29 Kasım). Necip Celâl Yok Ama Tango Yaşıyor. Milliyet Aktüalite. https://core.ac.uk/download/pdf/80954317.pdf

Ünlü, C. (2004). Git zaman gel zaman, Fonograf-gramofon-taş-plak. Pan Yayıncılık.

Yarkın, M. B. (2017). Tango Müziğinde Piyano İcrasının Carlos Di Sarli, Anibal Troilo ve Horacio Salgan Stilleri Üzerinden Incelenmesi. [Yüksek Lisans Tezi, İstanbul Teknik Üniversitesi]. İstanbul. https://polen.itu.edu.tr/handle/11527/15223

Yener, S. (2020). Türk Tango Müziklerinin Makam ve Usûl Yönünden İncelenmesi. İdil Dergisi, 65, 365-375. https://doi.org/10.7816/idil-09-66-14 